\title{
Enhancing Student Engagement with Their Studies: A Digital Storytelling Approach
}

\author{
Eunice Ivala ${ }^{1}$, Daniela Gachago ${ }^{1}$, Janet Condy ${ }^{2}$, Agnes Chigona ${ }^{2}$ \\ ${ }^{1}$ Fundani Centre for Higher Education Development, Cape Peninsula University of Technology, \\ Cape Town, South Africa \\ ${ }^{2}$ School of Education and Social Sciences, Cape Peninsula University of Technology, Cape Town, South Africa \\ Email: ivalae@cput.ac.za
}

Received August $2^{\text {nd }}, 2013$; revised September $2^{\text {nd }}, 2013$; accepted September $9^{\text {th }}, 2013$

\begin{abstract}
Copyright (c) 2013 Eunice Ivala et al. This is an open access article distributed under the Creative Commons Attribution License, which permits unrestricted use, distribution, and reproduction in any medium, provided the original work is properly cited.
\end{abstract}

\begin{abstract}
Higher education institutions in South Africa are faced with low throughput rates, and the need to enhance students' interest in their studies is a key objective for higher education institutions. Student engagement is one of the factors shown empirically to enhance student success at higher education institutions. The paper reports on the potential of digital storytelling in enhancing student engagement with their studies, amongst 29 final year pre-service student teachers at a large University of Technology in South Africa, as part of their assessment in their final year professional course. The reason for doing this research was due to the limited adoption of digital storytelling in conventional educational settings globally and the fact that little research has been done internationally and particularly in South Africa, into how digital storytelling can be a vehicle for expanding learning. The study was framed around the engagement construct involving qualitative methods of collecting data. Focus group interviews were conducted with the students and the facilitators of the project to elicit whether the production of digital stories led to student engagement. Focus group interviews were analyzed using inductive strategy. Results showed that the production of digital stories enhanced student engagement with their studies which led to high levels of reflection on the subject matter, which as a result led to a deep understanding of the subject matter. Findings of this study will contribute knowledge in the field which may be valuable in increasing student engagement with their studies.
\end{abstract}

Keywords: Student Engagement; Engagement Construct; Digital Storytelling; Digital Stories; Digital Literacy Skills

\section{Introduction}

Higher education institutions (HEIs) in South Africa are faced with low throughput rates (Swanepoel et al., 2009; Scott et al., 2007), and the need to enhance students' engagement in their studies is a key objective. Student engagement (the amount of physical and psychological energy that students devote to educationally purposeful activities) is one of the factors shown empirically to enhance student success at HEIs (Astin, 1977, 1985; Gellin, 2003; Pike, Kuh, \& Gonyea, 2003; Pike, Schroeder, \& Berry, 1997). In response to the above challenge, this study investigated the potential of digital storytelling in enhancing student levels of engagement with their studies, amongst 29 final year pre-service student teachers at a large University of Technology in South Africa, as part of their assessment in their final year professional course. The study was formed by the engagement construct (Kuh, 2009) which helped the researchers in understanding the potential of digital storytelling in enhancing student engagement with their studies. The engagements construct holds that the level of student engagement is positively related to gains in the desired outcomes, their general abilities or critical thinking; is also positively linked to grades and retention rates. The above tenets guided the re- searchers in this study.

The study utilized qualitative methods of collecting data. Focus group interviews were conducted with the students and their facilitators (inclusive of the lecturer) to elicit whether the production of digital stories led to student engagement with the subject matter. Findings of the study showed that the production of digital stories enhanced students' level of engagement with their studies, which led to high levels of reflection on the subject matter, which as a result, led to a deep understanding of the subject matter. The researchers recommend that digital storytelling should be used more in pre-service teacher programmes because they expand learning beyond the traditional face-face methods of teaching and learning and lead to high levels of student engagement with their studies. Additionally, the researchers suggest that there is need to implement digital storytelling in disciplines other than education to ascertain whether the results are replicable or not.

\section{Literature Review: Digital Storytelling and Student Engagement}

Digital stories are defined differently by different authors (Banaszewski, 2005; Barrett, 2006; Mills, 2010; Long, 2011). 
However, the working definition for this study is that, digital stories are short, first person video-narratives created by combining recorded voice, still and moving images and music or other sound. Digital stories are produced by someone who is not a media professional, and usually constructed as a thought piece on a personal experience (Matthews-DeNatale, 2008). These non-professionals position themselves as "authors", composers, and designers who are expert and powerful communicators, with things to say that the world should hear (Hull et al., 2006: p. 10). Digital stories have a variety of uses: telling of personal tales, recounting of historical events, or as a mean to inform or instruct on a particular topic etc. Digital storytelling shifts the focus of the classroom away from the teacher, a model that has dominated education since the 18th Century, to the student (Banaszewski, 2005; Knapper, 2001). The basic paradigm shift is from an educational emphasis on people as recipients of information and knowledge to an emphasis on people as participants in the creation of information and knowledge (Freire, 2001; Ohler, 2006; Tyner, 1998). The creation of the digital stories involves incorporating multimedia components such as images, music, video, and narration, which is usually the author's own voice (Barrett, 2006, 2008; Dogan \& Robin, 2006) and to deliberately make explicit their own thoughts and actions whereby fostering reflection.

If well integrated in schools/universities, digital storytelling can enhance facilitation of a wide range of substantial educational benefits: acquisition and consolidation of knowledge and skills; heightened engagement, motivation towards learning activities, and also acquisition of digital literacy skills (Blas, Garzotto, Paolini, \& Sabiescu, 2009). Digital storytelling allows students to develop their personal and academic voice, present knowledge to a community of learners and receive situated feedback from their peers. Due to their affective involvement with this process and the novelty effect of the medium, students are more engaged than in traditional assignments. These factors can create a "spiral" of engagement, drawing students into deeper and deeper engagement with their topics or studies (Coventry \& Oppermann, 2009). Digital storytelling's combination of video, sound, images and student voice creates an environment where students become deeply invested in their topics or subjects under study. Digital storytelling increases engagement through interactivity. It improves students' teamwork capabilities through the thick social interaction students engage in during the production, than other school activities do (Blas, Garzotto, Paolini, \& Sabiescu, 2009). Digital stories mediate the academic conversations students conduct with their peers and with staff, management of their learning, how they document, distribute and apply their knowledge, or the time they spend really trying to understand a topic. Furthermore, creating digital stories increases students' motivation and engagement levels (Dogan \& Robin, 2008; Salpeter, 2005), especially the director's chair effect, self expression and opportunity to utilize technology as a key factors in captivating and motivating students (Banaszewski, 2005; Paul, 2002; Dogan \& Robin, 2008).

Despite growing recognition of the importance of student engagement and the potential impact of digital stories on student engagement, little research has been done internationally and in South Africa into how the adoption of digital storytelling as a vehicle for expanding learning is creating new patterns of engagement. Additionally, the adoption of digital storytelling in conventional educational setting is currently limited; most reported educational projects based on these systems are largely based on episodic, short-term experiences involving a limited number of teachers and students for a short period (Blas, Garzotto, Paolini, \& Sabiescu, 2009) and the little research available is from developing countries. As a result, only limited research is available to guide best practice. Thus, the reason why the researchers in this study set to investigate the potential of digital storytelling in enhancing student levels of engagement with their studies in an African context, specifically amongst 29 final year pre-service student teachers at a large University of Technology in South Africa. The study aims tofurther research in this field, and is guided by the following question: what is the potential of digital storytelling in enhancing pre-service teacher students' levels of engagement with their studies?

\section{Theoretical Framework}

The study was informed by the engagement construct which has been in the literature for more than seventy years, with the meaning of the construct evolving over time (Kuh, 2009). The earliest use of the engagement construct was by Ralph Tyler, who showed the positive effects of time on task on learning (Merwin, 1969). In the 1970s, Pace developed the College Student Experiences Questionnaire (CSEQ), which was based on what he termed "quality of efforts". He showed that students gained more from their studies and other aspects of the college experience when they invest more time and energy in educationally purposeful tasks such as: studying; interacting with their peers and teachers about substantive matters; applying what they are learning to concrete situations and tasks etc. (Pace, 1990). Alexander Astin (1984) fleshed out and popularized the quality of effort concept with his "theory of involvement" in which he emphasized importance of involvement to student achievement. Since then, different scholars have contributed lots of papers addressing different dimensions of student effort and time on task and their relationship to various desired outcomes of college (Pascarella \& Terenzini, 2005; Pike, 2006; Tinto, 1987, 1993).

Today, engagement is the term usually used to represent constructs such as quality of effort and involvement in productive learning activities (Kuh, 2009) and student engagement is measured differently by different scholars. Engagement is conceptualized as the time and effort students invest in educational activities that are empirically linked to desired college outcomes (Kuh et al., 2008). Engagement encompasses various factors, namely: investment in the academic experience of college; interactions with faculty; involvement in co-curricular activities, and interaction with peers (Pascarella \& Terenzini, 2005; Kuh, 2009). Kuh (2009) emphasizes two major facets: in-class (or academic) engagement and out-of-class engagement in educationally relevant (co-curricular) activities, both of which are important for student success.

Thus, the factors that influence student's level of engagement are either student-based or institution-linked (Strydom et al., 2010). Student behaviours which are linked to engagement include study habits, time on task ${ }^{1}$, interaction with staff, peer involvement, and motivation (Eccles \& Wigfield, 2002). According to the Student-engagement construct (Astin, 1984,

\footnotetext{
${ }^{1}$ Time on task has two meanings: one is to do with how long the students have been in college; the other is to do with how many hours a week the students usually spend on activities related to their school work (Pace, 1982: p. 22; Spanjers et al., 2008).
} 
1985), institutional policies and practices influence levels of student engagement on campus. Certain institutional practices are known to lead to high levels of student engagement (Chickerring \& Reisser, 1993; Pascarella \& Terenzini 1991). These include student-faculty contact, cooperation among students, active learning, prompt feedback, time on task, high expectations, and respect for diverse talents and ways of learning. Also important to students' learning are institutional environments that are perceived by students as inclusive and affirming and where expectations for performance are clearly communicated (Kuh, 2001). Institutions influence student engagement by the way in which they "allocate resources and organise learning opportunities and services to induce students to participate in and benefit from such activities” (Kuh et al., 2005: p. 9). Thus, measures of student engagement that guided the researchers in understanding the issue under investigation in this study were: interaction with staff; interaction with peers; time on task (in-class and out-of-class engagement in educationally relevant activities (Kuh, 2009); policies and practices; applying what they are learning to concrete situations and tasks (Pace, 1990); motivation; active learning; prompt feedback; respect for diverse talents and ways of learning (Chickering \& Reiser, 1993; Pascarella \& Terenzini, 1991).

\section{Background of the Case Study}

The project ${ }^{2}$ was carried out in 2010, with final year preservice students in the Faculty of Education and Social Sciences at a large University of Technology in South Africa. The lecturer considered using of digital storytelling in the professional development course in order to help students acquire reflective skills. The course was structured into two block sessions, a face-to-face and teaching practice sessions. Students produced their digital stories during the face-to-face sessions whereby they were provided an environment where facilitators actively encouraged them to speak their minds, were interested to hear what the students had to say, responded respectively to students' ideas and treated them as knowledgeable members of the class. It is in this kind of environment that 60 pre-service student teachers were introduced to the art of digital storytelling. Before embarking on their own stories, students were shown a model story developed by their lecturer as they were not familiar with the digital story genre. The seed story shown was on the lecturer's reflection on her thirty years of being a teacher. After the introduction to the art of digital storytelling, 31 students opted to write a paper-based portfolio for their assessment, leaving 29 students to embark on the journey of digital storytelling for their final year assessment in the professional course. In this assessment, all the 60 students were required to reflecton-action ${ }^{3}$ on the seven roles of a teacher ${ }^{4}$.

The project took eight weeks, commencing with students writing a script for their stories. After each student wrote drafts

\footnotetext{
${ }^{2}$ This study is a continuation of the study by Ivala et al. (2011) on digital storytelling and enhancement of reflection amongst 29 pre-service student teachers and their lecturers at CPUT.

${ }^{3}$ Reflection-on-action involves students reflecting and contemplating on issues after the issue had taken place (Schön, 1983).

${ }^{4}$ Currently the South African national teacher curriculum is based around the seven roles of the teacher, which include: mediator of learning; interpreter and designer of learning programmes and materials; leader, administrator or and manger; community, citizenship and pastoral role; scholar, researcher and lifelong learner; assessor; and learning area/subject/discipline/phase specialist (South African Government Gazette No. 20844).
}

of the story, the facilitators provided constructive feedback, on each draft, giving suggestions on how to shape the stories to not exceed the required word count of 500 words. It is important to note that the first drafts of the students story scripts were too long (in some cases more than 5 pages) and content followed the examples shown by their lecturer and therefore had no connection with the seven roles of the teacher as per the assignment brief. This resulted in students writing several drafts. Students worked in groups (self-selected) mostly based on language and race and within and across these groups, students gave feedback on each other's script. After writing the script, students turned their written script into digital audio files by recording their voices as they read their stories using a software programme called Audacity ${ }^{5}$. They then located, scanned or took digital photographs to accompany their words, found images on the Internet to enrich their stories, recorded background songs or downloaded songs from the Internet. They ended the process by bringing these multiple media together (using MS Movie Maker) ${ }^{6}$ to make a short (around 5 minutes long) powerful and personally meaningful digital stories that clearly and movingly spoke to the other members of the class. The production of the story took place both off and on-campus in a dedicated student laboratory. The final story was presented to staff of the Faculty of Education and Social Sciences, students' parents and the students themselves. See Figure 1 below for a schematic representation of the digital storytelling process.

\section{Methodology}

The study utilized qualitative methods of collecting data.

\section{Participants and Context}

The study was conducted in 2010, with 29 final year preservice students in the Faculty of Education and Social Sciences. The study was located in this faculty and subject, because of the lecturer's and students' willingness to participate in the study. Three staff members from the academic development centre at this university facilitated the project. Convenience sampling was therefore used for this study.

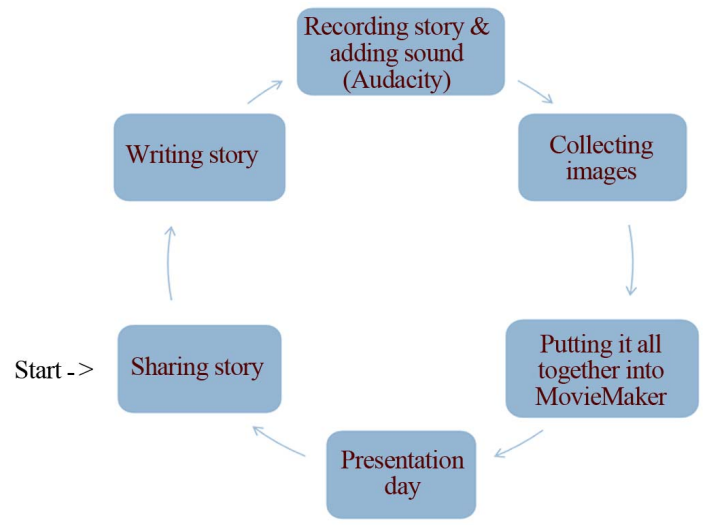

Figure 1.

Digital storytelling process.

${ }^{5}$ For details on what audacity is see

http://wikieducator.org/Using_Audacity/What_is_Audacity

${ }^{6}$ For details on what Window Movie Maker is see

http://en.wikipedia.org/wiki/Windows_Movie_Maker. 


\section{Data Collection and Analysis}

Data was gathered from three focus group interviews with the students and one focus group interview with the facilitators (inclusive of the lecturer) of the project to elicit whether the production of digital stories led to student engagement. Focus group interview data was recorded on tape and transcribed verbatim. The interviews were analyzed focusing on the identification of conceptual themes and issues emerging from the data, using techniques such as clustering, and making contrast and comparisons (Miles \& Huberman, 1994). The researchers were especially interested in moments in the project that could be construed as the focal points for students' engagement with their studies.

\section{Trustworthiness}

The trustworthiness of information gathered in this study was ensured by members of the research team discussing the research process, the congruency of the emerging findings with the raw data, and tentative interpretations which promoted validity. Descriptive validity (Maxwell, 1992) was ensured by tape recording participants' focus group discussions and transcribing the discussions verbatim with an aim of quoting as accurately as possible what the participants' had said. Interpretive validity was also adhered to as the researchers in this study sought to understand the phenomena from the participants' perspectives and categories (Bohman, 1991). The researchers also employed the engagement construct to understand the issue under investigation, thus promoting theoretical validity. The researchers in this study acknowledge that findings of this study are not generalisable, but offer valuable insights, which others interested in the implementation of digital storytelling in their curriculum delivery, could draw from.

\section{Statement of Ethics}

During the course of the study, all participants were treated with respect and sensitivity. Activities carried out during the study were negotiated with the participants and informed consent was sought from every participant participating in the study. Participants were also assured anonymity. Furthermore, ethical clearance was obtained from Research Ethics Committee of the institution.

\section{Limitations of the Study}

The purpose of this study was neither to measure students' attitudes to digital storytelling, nor to focus on the impact of digital storytelling on student performance. The study focused on the potential of digital storytelling in enhancing student engagement with their studies, as perceived by the students and the facilitators of the digital storytelling project. This means that no statistics on student attitudes and performance will be presented in this paper. Further research will need to be carried out to establish students' attitudes on digital storytelling and the impact of digital storytelling on students’ performance.

\section{Results and Discussion}

The paper reports on the potential of digital storytelling in enhancing student engagement with their studies from a students' and facilitators' perspective. Based on the analysis of the data, both the facilitators' and the students' who participated in this project reported that digital storytelling enhanced students' engagement with the subject matter at hand. Participants indicated that the following factors enhanced their engagement with their studies: extended opportunities for study beyond the classroom time; motivation to interact with the subject content; student control of their own learning; the process of producing digital stories; peer learning and increased student-lecturer interactions and promotion of high levels of reflection. Results on digital storytelling and enhancement of student engagement will be discussed under the aforementioned factors.

\section{Extended Opportunities for Study beyond the Classroom Time}

One of the factors given for enhancing students' levels of engagement with their studies by both the facilitators and the students who participated in the digital storytelling project was the extended opportunities for study beyond the classroom time. Carroll and Carney's (2005) argued that giving students' a chance to communicate their personal stories prompts them to invest much more time and effort in the project than it may be required (see also Coventry \& Oppermann, 2009). Findings of this study showed that students engaged deeply with the production of their stories and hence the subject matter both at home and on campus, as indicated in the following staff and student quotes:

Staff A: ... there is this student, I helped her with her story throughout...I helped her edit her story, I helped her record her story, I helped her put it together, the music. I knew what was in her story but when it came to the presenting, I was shocked because I had no idea of the words that were coming out of that machine. Meaning that she worked on it in class but when she found the skills that she needed she went and re-did it... so it means that when she got home she went back to it and started it again...

Student C: I also did most of my work at home, like writing out the story and asking when I came to campus, asking the lecturers maybe to edit and just to check if my story is according to how it's supposed to be... and would do the typing on campus.

The above results demonstrate that literacy demands and practices of college life infiltrated home life and that students spend considerably more time (than when doing usual paper based portfolios or assignments) on campus, outside of class time and off-campus to work on their stories. These results are in line with the engagement construct factor of in-class and outof-class engagement in educationally relevant activities (Kuh, 2009).

\section{Motivation to Interact with the Subject Content}

The motivation to interact with the subject content was another factor given for enhancing student levels of engagement with their studies. In this regard, finding servealed that the digital storytelling project motivated students to interact with the content on the seven roles of the teacher:

Student B: ... it [producing a digital story] was so much exciting than rather doing....all the paper based assignments that we always have to do...you know it actually 
was something that we wanted to come, we wanted to do it and we loved every minute of it. It's not often that you get an assignment that you actually really enjoy doing.

Based on the above results, the lecturer's choice of using digital stories for assessment motivated these students' in handling the task in question more than any of the previously used paper based ways of assessment (Ames, 1992; Blas, Garzotto, Paolini, \& Sabiescu, 2009). These findings are in line with the engagement construct point of view that certain institutional practices are known to lead to high levels of student engagement (Astin, 1985; Chickering \& Reisser, 1993; Pascarella \& Terenzini, 1991). As a result of this practice [digital storytelling], the students were deeply involved in their learning.

\section{Student Control of Their Own Learning}

Another factor which enhanced students' levels of engagement in their studies was the student control of their own learning. Students reported that the production of digital stories gave them control of their learning and enabled them to tell their stories in their own voice:

Student D: ... its [producing of digital stories] is very personalized. It comes from your perspective and then other people can relate to that....whereas when you write something [paper based assignment] it comes out very factual especially at this university level... people read something that you've written and they have a slightly different interpretation as you do in your head. Whereas this [digital story] you've got the images right there and you've got the words and the music. The tone is set. The mood is set and the pictures are there to show things from how you experience it and how you see it. So I think it's much more affective actually.

These results show that through the production of digital stories, students actively engaged (had internal interactions with themselves) in making sense of their experiences (Chickering \& Reisser, 1993; Pascarella \& Terenzini, 1991) and reflected more deeply about the design process (McKillop, 2005) and the subject matter. This internal interaction is important since it is the process of intellectually interacting with content that results in changes in the learner's understanding, perspective, or the cognitive structure of the learners mind (Moore, 1989) and initiates learners' internal interaction about the information and ideas they encounter in a course and constructs it into knowledge with personal application and value (Dewey, 1916).

\section{The Process of Producing Digital Stories}

An additional factor given by the facilitators and students for enhancing their levels of engagement with their studies was the process of producing digital stories. Results revealed that the whole process of producing digital stories enhanced students' engagement with the subject matter.

Staff B: ... I must say most of them took it really seriously to a point that they wanted it to be as we said..., they re-did it and re-did it and re-did it and some of them just recorded again in class, two, three, four times on their own and they also went back... and recorded a background song again...

Student A: ... I have to look at how long we had to take just to write that thing [the story script] out. You write it out, that's the first draft. Then you're going to write it out again. That's your second draft. Third draft, fourth draft. You know it takes long, just thinking because you need to okay that sentence doesn't fit there... That takes time and I mean even the pictures... it took me eight hours getting pictures from Flicker...

The results show that all stages of the digital storytelling production process (writing the story, directing their own digital story, illustrating and collecting images, selecting images, combining images, music and voice and sequencing them to make the story) appeared to stimulate students' emotional connection, effort and interest in the subject matter and hence student engagement. Thus the above experiences may have resulted in a deeper understanding of the subject matter.

\section{Peer Learning and Increased Student-Lecturer Interactions}

Furthermore students indicated that their levels of engagement with their studies were enhanced by peer learning and increased student-lecturer interactions. Results showed that through the production of digital stories, students benefited immensely from the influence and expertise of peers, as evidenced in the following quotes:

Student E: ... Because like [student] C knew exactly what was going on with all the programming whereas with writing and stuff, I would be fine on my own. Just like [student] A, but without $\mathrm{C}$ my movie would have been very different and without sort of $\mathrm{D}$ saying this sounds good, that sounds bad, or you know we kind of, we bounced ideas off each other.

Student C: ... working with other students, I mean, there might have been students that you never even spoke to. I mean for four years we've been together and to be honest you've never said a word to that person but during this, doing this [production of digital stories] we just opened up.

The above findings revealed that students learned enormously from each other by advising and giving feedback to each other. According to Bruce and Lin (2009), this kind of students' dialogues constitute an intellectual layer of meaning making, one that inspires the students to think seriously about effective communication and the quality of their stories (Blas, Garzotto, Paolini, \& Sabiescu, 2009). Furthermore, the results also indicate that the project helped students to create a learning community which did not exist before. Wenger, McDermott and Snyder (2002) argue that peer interactions is critical to the development of communities of learning that allow students to develop interpersonal skills, and to investigate tacit knowledge shared by community members as well as a formal curriculum of studies. Students also benefited from the high levels of interaction with the facilitators. Facilitators of the project, who were themselves lecturers at the university assisted students by giving continuous feedback when needed, on all the steps needed for the production of the digital stories.

Staff C: One, interpersonal relationships with the students. That was really interesting because initially we showed them a video and they tried to copy what they saw. And in the first instances you had to basically get them away 
from what they saw and get them to be busy with the five or the seven roles of the teacher and that took a bit of confrontation... the moment they realized what they had to do, then they allowed me in and there was an incredible mix, ... a linkage between me and the students after a while which was lekker [means good] to play around with...

Student B: I also did most of my work at home like writing the story and... asking the lecturers maybe to edit and just check if my story is according to how it's supposed to be... according to the criteria.

The above results suggest that digital storytelling supported a learning environment rich with student-student, student-lecture and student-content interactions. Anderson (2003) argued that sufficient levels of deep and meaningful learning can be developed, as long as one of the above types of interactions is at very high levels. Additionally, the results are in line with the students' and institutional factors that influence student levels of engagement. These factors are time on task, time spend in class and out-of-class on educationally purposeful activities, interaction with lecturers, and interaction with peers and motivation (Eccles \& Wigfield, 2002; Pascarella \& Terenzini, 2005; Kuh, 2009).

\section{Promotion of High Levels of Reflection}

The promotion of high levels of reflection is another factor given by both the facilitators and the students for enhancing their levels of engagement with their studies. Both staff and students unanimously felt that digital storytelling promoted high levels of reflection which led to deep learning or understanding of the subject matter, as evidenced in the following quotes:

Staff: This particular experience was a brilliant way of doing it because they [the students] really had to engage with their studies, the last four years. What they have done, what they accomplished, how they learnt to be a better teacher, so it really got them to engage... they said they can see now what they've learnt and if they left university without doing it [digital storytelling] it would be leaving in a vacuum... this experience helped them to crystallize all their learning...

Student: ... it made me understand more what they meant [seven roles of the teacher], because I've always known what the seven roles of the teacher are, but I didn't actually know what they meant and what they meant to me, but now doing it with the digital story and actually incurporating it to my story, I kind of understood what they're about and what those seven roles-basically I didn't understand what they were but after the story now I know what they mean and what they are.

The deeper reflection promoted by digital storytelling is said to have promoted a deeper understanding in a subject content which had previously been taught using the lecture method and understood superficially by the students.

\section{Conclusion and Recommendations}

In general, findings of this study showed that digital storytelling provided expanded opportunity for the students to engage and plug deeper into the subject matter. Factors which led to high levels of student engagement were: extended opportunities for study beyond the classroom time; motivation to interact with the subject content; student control of their own learning; the process of producing digital stories; peer learning, increased student-lecturer interactions and promotion of high levels of reflection. The researchers echo Herrington's (2003) finding that student engagement is paramount to learning success as the provision of expanded opportunity to interact with the subject matter in the course understudy, led to high student levels of engagement with the subject matter which enhanced student motivation and interest in the subject matter and hence deep and meaningful understanding of the subject content.

Based on the findings of this study, the researchers argue for recognition of and support for digital storytelling as an alternative method of assessment in teacher education, which extends teaching and learning beyond the classroom and hence high levels of student engagement with their studies. The researchers are of the opinion that for appropriate integration, digital storytelling should be embedded in the curriculum and not used as an add-on or a fad way of assessing learning. While the study demonstrates the potential of digital storytelling for students engagement in teacher education, a major question of sustainability and replication to other disciplines remains. The researchers suggest that there is need to implement digital storytelling in other disciplines other than education in order to establish whether the results are replicable or not.

The researchers also suggest that there is need for more researches to ascertain if higher levels of engagement would be experienced by students through using digital storytelling to engage with subject content which has not been previously taught using a different delivery method. Since Dewey (1913) pointed out the relationship between effort and interest and how this interacts in producing good result, the researchers suggest that further research is needed to gauge whether the increased levels of student engagement promoted by digital storytelling translate to improved student performance (in terms of marks).

\section{Acknowledgements}

An earlier version of the paper appears in the proceedings of the 7 International Conference on e-Learning: Ivala, E., Chigona, A., Gachago, D. \& Condy, J. (2012). Digital Storytelling and Student Engagement: A Case of Pre-service Student Teachers and their Lecturers at a University of Technology. This paper has been substantially revised based on the discussions at the conference as well as the valuable comments from the editor of special issue of Electronic Journal of e-Learning who had selected the paper for possible publication in the special issue.

\section{REFERENCES}

Ames, C. (1992). Classrooms: Goals, structures and student motivation. Journal of Educational Psychology, 84, 261-271.

http://dx.doi.org/10.1037/0022-0663.84.3.261

Anderson, T. (2003). Getting the mix right again: An updated and theoretical rationale for interaction. The International Review of Research in Open and distance learning, 4.

http://www.irrodl.org/index.php/irrodl/article/view/149

Astin, A. W. (1977). Four critical years. San Francisco: Jossey-Bass.

Astin, A. W. (1984). Student involvement: A developmental theory for higher education. Journal of College Student Development, 25, 297- 
308.

Astin, A. W. (1985). Involvement: The cornerstone of excellence. Change, 17, 35-39.

http://dx.doi.org/10.1080/00091383.1985.9940532

Banaszewski, T. M. (2005). Digital storytelling: Supporting digital literacy in grades 4-12. Masters of Science thesis, USA: Georgia Institute of Technology.

Barrett, H. (2006). Digital stories in eportfolios: Multiple purposes and tools.

http://electronicportfolios.org/digistory/purposes.html

Barrett, H. (2008). Multiple purposes of digital stories and podcasts in eportfolios.

http://electronicportfolios.com/portfolios/SITE2008DSpaper.pdf

Blas, N. D., Garzotte, F., Paolini, P., \& Sabiescu, A. (2009). Digital storytelling as a whole-Classlearning activity: Lessons from a threeyear project. Proceedings of the 2nd Joint International Conference on Interactive Digital Storytelling. Heidelberg,: Springer-Verlang.

Bohman, J. (1991). New philosophy of social science. Cambridge, MA: MIT Press.

Bruce, B., \& Lin, C (2009). Voices of youth: Podcasting as a means of inquiry-based community engagement. E-Learning and Digital Media, 6, 230-241. http://dx.doi.org/10.2304/elea.2009.6.2.230

Carroll, D., \& Carney, J. (2005). Personal perspectives: Using multimedia to express cultural identity: Contemporarily issues in Technology and Teacher Education.

http://www.citejournal.org/vol4/iss4/currentpractice/article2.cfm

Chickering, A. W., \& L. Reisser, L. (1993). Education and identity (2nd ed.). San Francisco: Jossey-Bass.

Chickering, A. W., \&Garmson, Z. F. (1987). Seven principles for good practice in undergraduate education. American Association for Higher Education Bulletin, 39, 3-6.

Coventry, M., \& Oppermann, M. (2009). From narrative to database: Multimedia inquiry in across-classroom scholarship of teaching and learning.

http://www.academiccommons.org/commons/essay/narrative-database

Dewey, J. (1913). Interest and effort in education. New York: Houghton Mifflin.

Dogan, B., \& Robin, B. (2006). Implementation of digital storytelling in the classroom by teachers trained in a digital storytelling workshop.

http://digitalstorytelling.coe.uh.edu/pdfs/Dogan-DS-Research-2008.p df

Dogan, B., \& Robin, B. (2008). Implementing of digital storytelling in the classroom by teachers trained in a digital storytelling workshop. In Proceedings of society for Information Technology and Teacher Education International Conference. Chesapeake, VA: AACE. http://www.edtlib.org/f/27287

Eccles, J. S., \&Wigfield, A. (2002). Motivational beliefs, values, and goals. Annual Review of Psychology, 53, 109-132. http://dx.doi.org/10.1146/annurev.psych.53.100901.135153

Freire, P. (2001). Pedagogy of freedom: Ethics, democracy and civic courage. London: Rowmanand Littlefield Publishers.

Gellin, A. (2003). The effect of undergraduate student involvement on critical thinking: A meta-analysis of the literature, 1991-2000. Journal of College Student Development, 44, 746-762. http://dx.doi.org/10.1353/csd.2003.0066

Herrington, J., Oliver, R., \& Reeves, C. (2003). Patterns of engagement in authentic online learning environments. Australian Journal of Educational Technology, 19, 51-55.

Hull, G., Kenny, N. L., Marple, S., \& Forman-Schneider, A. (2006). Many versions of masculine. After school matters. The Robert Browne Foundation.

http:///www.uclinks.org/rreference/research/Hulletal.Masculinitypap er.pdf

Ivala, E., Gachago, D., Condy, J., \& Chigona, A. (2011). Digital storytelling and reflection in higher education: A case of pre-service student teachers and their lectures' at a University of Technology. Paper submitted for consideration for publication to The Journal for Transdisciplinary Research in Southern Africa.

Knapper, C. (2001). The challenge of educational technology. The International Journal for Academic Development, 6, 92-95.
Kuh G. (2009). Improving undergraduate success through student engagement. Presentation to Council for Higher Education, Pretoria: SA.

Kuh, G. D. (2001). Assessing what really matters to student learning: Inside the national survey of student engagement. Change, 33, 10-13. http://dx.doi.org/10.1080/00091380109601795

Kuh, G. D., \& Others (2008). Unmasking the Effects of Student Engagement on College Grades and Persistence. Journal of Higher Education, 79, 540-563. http://dx.doi.org/10.1353/jhe.0.0019

Kuh, G. D., Schuh, J. H., Whitt, E. J., \& Associates (1991). Involving colleges: Encouraging student learning and personal development through out-of-class experiences. San Francisco: Jossey-Bass.

Kuh, G. D., Whitt, E. J., \& Strange, C. C. (1989). The contributions of institutional agents to high quality out-of-class experiences for college students. Paper presented at the annual meeting of the American Educational Research Association, San Francisco.

Kuh, G. G., Kinze, J., Shuh, J. H, Whitt, E. J., \& Associates (2005). Student success in college: Creating conditions that matter. San Franisco: Jossey-Bass.

Long, B. (2011). Digital storytelling and meaning making: Critical reflection, creativity and Technology in pre-service teacher education. http://lillehammer2011.files.wordpress.com/2010/10/bornie-long-con ference-paper.pdf

Maehr, M. L., \& Midgley, C. (1991). Enhancing student motivation: A school-wide approach. Educational Psychologist, 26, 399-427.

Matthews-DeNatale, G. (2008). Digital storytelling-Tips and resources.

http://www.educause.edu/Resources/DigitalStoryMakingUnderstandi n/162538

Maxwell, J. A. (1992). Understanding and validity in qualitative research. Harvard Education Review, 62, 279-299.

McKillop, C. (2005). Storytelling grows up: Using storytelling as a reflective too in higher education. Paper Presented at the Scottish Educational Research Association Conference, 24-25 November.

Merwin, J. C. (1969). Historical review of changing concepts of evaluation. In R. L. Tyler (Eds.), Educational evaluation: New roles, new methods: The sixty-eighth yearbook of the National Society for the Study of Education, Part II. Chicago: University of Chicago Press.

Miles, M. B., \& Huberman, A. M. (1994). Qualitative data analysis (2nd ed.). Thousand Oaks: Sage.

Mills, K. A. (2010). A review of the "digital turn" in the new literacy studies. Review of Educational Research, 80, 246-271. http://dx.doi.org/10.3102/0034654310364401

Ohler, J. (2006). The world of digital storytelling. Learning the digital age. Educational Leaders, 63, 44-47.

Pace, C. R. (1990). The undergraduates: A report of their activities and college experiences in the 1980s. Los Angeles: Center for the Study of Evaluation, UCLA Graduate School of Education.

Pascarella, E. T., \& Terenzini, P. T. (1991). How college affects students: Findings and insights from twenty years of research. San Francisco: Jossey-Bass.

Pascarella, E. T., \& Terenzini, P. T. (2005). How college affects students: A third decade of research. San Francisco: Jossey-Bass.

Paul, C. N. (2002). Self-perceptions and social connects: Empowerment through digital storytelling in adult education. Dissertation Abstracts International (UMI No. 3063630).

Pike, G. R. (2006). The convergent and discriminant validity of NSSE scalelet scores. Journal of College Student Development, 47, 551564. http://dx.doi.org/10.1353/csd.2006.0061

Pike, G. R., Kuh, G. D., \& Gonyea, R. M. (2003). The relationship between institutional missions and students' involvement and educational outcomes. Research in Higher Education, 44, 243-263. http://dx.doi.org/10.1023/A:1022055829783

Pike, G. R., Schroeder, C. C., \& Berry, R. R. (1997). Enhancing the educational impact of residence halls: The relationship between residential learning communities and first-year college experiences and persistence. Journal of College Student Development, 38, 609-621.

Salpeter, J. (2005). Telling tales with technology. Technology and Learning, 25, 18,20,22,24.

Schön, D. (1983). The reflective practitioner. How professionals think 
in action. London: Temple.

Scott, I., Yeld, N., \& Hendry, J. (2007). Higher education monitor No.6: A case for improving teaching and learning in South African Higher Education. The Council on Higher Education, Pretoria.

Strydom, J. F., Mentz, M., \& Kuh, G. D. (2010). Enhancing success in higher education by measuring student engagement in South Africa. http://sasse.ufs.ac.za/dl/userfiles/documents/SASSEinpresspaper_1.p df

Swanepoel, E., De Beer, A., \& Müller, A. (2009). Using satellite classes to optimize access to and participation in first year Business Management: A case at an open and distance learning university in
South Africa. Perspectives in Education, 27, 311-319.

Tinto, V. (1987). Leaving college: Rethinking the causes and cures of student attrition (2nd ed.). Chicago: University of Chicago Press.

Tinto, V. (1993). Leaving college: Rethinking the causes and cures of student attrition. Chicago: University of Chicago Press.

Tyner, K. (1998). Literacy in a digital world: Teaching and learning in the age of information. New Jersey: LEA.

Wenger, E., McDermott, R., \& Snyder, W. (2002). Cultivating communities of practice: A guide to managing knowledge. Cambridge, MA: Harvard Business School Press. 